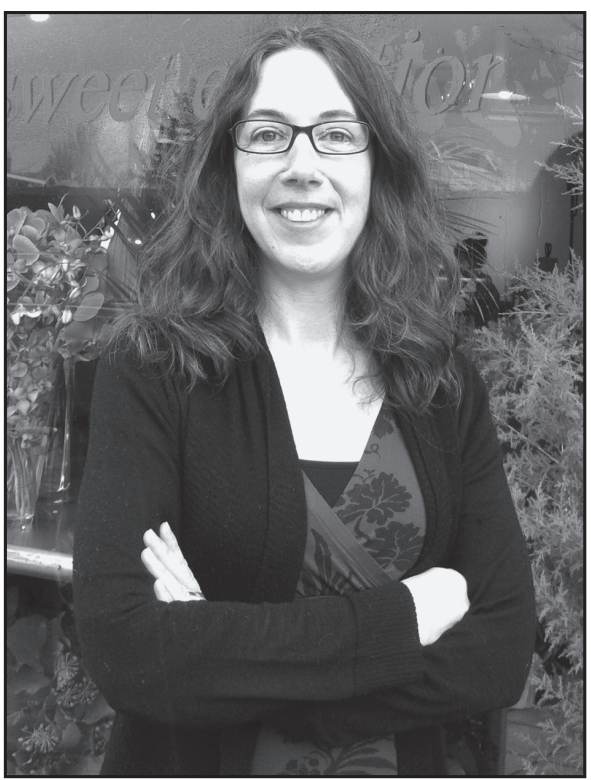

Iris Berger

PUBLICATIONS

CHAIRPERSON

Early Childhood Education in Canada: Are We in Motion or Are We Stepping Forward?

When children walk, very often they don't walk with the purpose of getting ahead. So many things can happen on the way; something interesting found on the sidewalk-a snail or a branch, or there is a discovery of walking being done backwards or in circles, or jumping on one leg.

$\sim \operatorname{Olsson}(2009$, p. 5)

\section{A History of Movements}

Last summer I taught a course about the history of early childhood education. Even though I have been teaching this course online for a number of years, the course this past summer stood out as a unique experience because it was offered in a face-to-face format. The daily encounters between the students and myself, the critical engagement with an array of historical figures, events, and phenomena, and the birthing and clashing of ideas, memories, questions, and discussions created a rich platform for putting the past in dynamic conversation with the present and rethinking some aspects of our field's history.

One word, in particular, seems to come back and haunt me after the experience of the history course. That word is movement. Those of you who are acquainted with the historical accounts of the field of early childhood education (ECE) will be familiar with the abundance of the movement terminology. For example, we frame periods of the field's history as the kindergarten movement (indicating the spread of the Froebelian kindergarten model across Europe and North America in the late 1800s), the child study movement (linked with the inauguration of the scientific investigation of child development in the early 1900s), and the progressive education movement (associated with John Dewey's childcentred pedagogy of the 1920s). The more I reflected on the word movement, its meaning in the historical context of ECE, its connection with change, and its relation to current discussions within the field of ECE, the more I panicked. The term, which strongly conveys political flavour and fervour, seemed far removed from our present ECE experiences. For a while I could not think of what in our present day might be characterized as political movements in ECE- the kinds of movements that will be remembered and documented in the ECE history books about our era.

\section{Contemporary Movements in ECE}

Curious about what might be identified with movement in our contemporary ECE landscape, I entered the subject heading "movement in early childhood in Canada" into a Google search box. To my surprise, when I hit the return key, the first link that came up was an edited book by Veronica Pacini-Ketchabaw and Alan Pence, two ECE scholars located in B.C. at the University of Victoria (Veronica Pacini-Ketchabaw is, of course, a coeditor of Canadian Children). Their book, Early Childhood Education in Motion: The Reconceptualist Movement in
Canada (2005), is a collection of articles portraying Canadian interpretations, by way of research and practice, of the reconceptualizing early childhood education (RECE) movement that emerged in the early 1990s in the U.S. Scholars leading the RECE movement often ascribe to critical, feminist, and postmodern theories, and have always confessed to upholding a political agenda. They challenge long-held assumptions upon which ECE has been established (including the credibility and legitimacy of the historical movements that were mentioned in the previous paragraph), and they centre their scholarly efforts on advancing equity and social justice for children, educators, and families. Some of the topics addressed by RECE scholars are described by two of the movement's leaders, Beth Blue Swadener and Gaile Cannella (2007), as follows:

The early work from reconceptualists in our field questioned the promotion of universal prescriptions for "best practice" and other "grand narratives." Many of the reconceptualists based in the U.S. were doing anti-bias, full-inclusion or culture- and genderfocused research that sought to appreciate and support diversity in people, ideas and ways of being. We shared a concern about privileging particular sets of beliefs or forms of knowledge that can create power for certain groups of people and oppress others. (p. 25)

Along with the challenges posed to a universal view of childhood that is based on developmental theory and a critique of the idea of quality in ECE as a valuefree concept, the reconceptualists also questioned the conventional idea of change as an upward, predictable evolution, based on the "natural" process of progress. For example, in the introductory chapter to the aforementioned book, Pacini-Ketchabaw and Pence (2005) comment that

the prevailing metaphor in Canadian ECEC history is an evolutionary spiral. Early childhood educators are seen as 
having developed, since the days of the infant schools in the 1820 s, ever more sophisticated understandings of children and their development and appropriate care. The evolutionary spiral is consistent with the modernist view of "progress." (p. 13)

Rather than thinking about change or movement through the metaphor of an evolutionary process (stepping forward or upward toward an assumed best practice), Pacini-Ketchabaw and Pence suggest taking a revolutionary approach to change that entails rethinking our practices and examining the assumptions underlying our pedagogies. This deconstructive approach to change involves risk and uncertainty ("pulling the rug from under one's feet," as one educator put it), but it opens up a possibility to approach the idea of movement or change in such a way that it is, at least to some degree, free from the standards of the present that inevitably limit and constrain our thinking.

The Swedish ECE researcher Liselott Olsson also introduced new concepts for thinking about movement in early childhood practices. In her book, Movement and Experimentation in Young Children's Learning: Deleuze and Guattari in Early Childhood Education (2009), Olsson engages with complex ideas from the French philosophers Deleuze and Guattari to think about change as something that happens at the molecular or micro-political level, and not at the administrative or governmental level. According to Olsson, change is not something that is willed as much as it is something that "sneaks up behind one's back" (p. 74). Change happens within the relational fields of our practice in "little moments" when, for example, the curriculum plan breaks down and complex, unforeseen connections unfold in front of us. While curriculum involves a macropolitical decision, when it encounters situations within the classroom, "an enormous creativity is released that completely and continuously transforms and defines the curriculum," as something always "escapes" the plan in the actual encounter with the children (p. 75). The question about change, argues Olsson, has to change. Rather than asking how we can get from this predefined position to the next, we can ask: What are the conditions that most favour the continuous experimentation that releases creative forces in our classrooms? How can we remain open to such experimentation?

\section{Setting Early Childhood Education into Motion}

I believe that now is a good time to ask questions about change and movement because something else happened last summer. In July 2012, the travelling exhibit from Reggio Emilia, The Wonder of Learning: The Hundred Languages of Children, opened in New Westminster. The exhibit created an opportunity for a lot of movement here in B.C., including the CAYC national conference in October 2012. Yet, when this issue of Canadian Children is published, the exhibit will already be on display in another part of the world. And so perhaps it is time to pose the following question to ourselves: Do we want to take the Reggio Emilia approach, which has been an instigator of change within the Canadian ECE scene for almost 20 years, as a symbol for an incremental step forward - a destination, a yardstick to measure our "progress"-or, alternatively, can we challenge ourselves to see the exhibit as a provocation - an opening for questions for which we still do not know the answers, but towards which we can begin thinking and experimenting together?

In conclusion, I would like to go back to the quote at the beginning of this discussion, because I think that we can take our inspiration for a reconceptualized idea of movement from young children. While for us, as adults, walking becomes an automated, purpose-bound activity, supported by an illusion that we actually know where we are going, for a child, walking is not necessarily about stepping forward with a clear destination in mind. What keeps children moving is a constant desire for experimentation through which new worlds are discovered and new relations are generated. Clearly, we cannot simply set aside the need for a sense of direction and destination, but perhaps we could create the possibility (or the conditions) to experience moments in which change might sneak up behind our backs.

\section{References}

Olsson, L. (2009). Movement and experimentation in young children's learning: Deleuze and Guattari in early childhood education. New York, NY: Routledge.

Pacini-Ketchabaw, V. \& Pence, A. (2005). Chapter 1: Contextualizing the reconceptualist movement in Canadian early childhood education. In V. PaciniKetchabaw \& A. Pence (Eds.), Early childhood education in motion: The reconceptualist movement in Canada (pp. 5-20). Ottawa, ON: Canadian Child Care Federation. Available online (chapter 1 only) at http:// www.cyc.uvic.ca/uccr/pubs

Swadener, B. \& Cannella G. (2007). Reconceptualizing early childhood education in North America: A brief introduction. Canadian Child Care Federation, Winter, 25-26. Retrieved from http://www.cyc.uvic.ca/uccr/ documents/ 